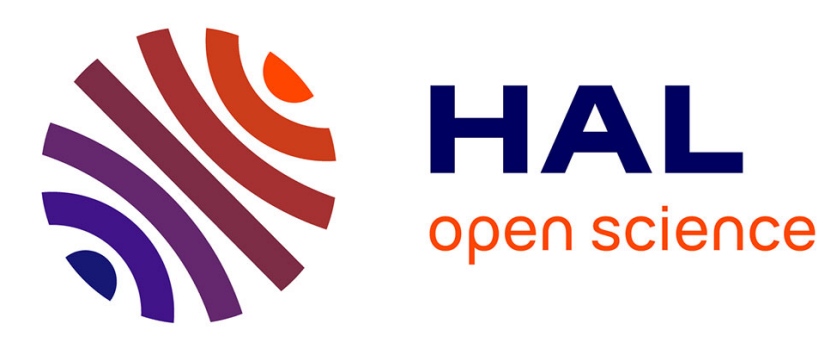

\title{
An optical catechol biosensor based on a desert truffle tyrosinase extract immobilized into a sol-gel silica layered matrix
}

Saida Leboukh, Hicham Gouzi, Thibaud Coradin, Harek Yahia

\section{- To cite this version:}

Saida Leboukh, Hicham Gouzi, Thibaud Coradin, Harek Yahia. An optical catechol biosensor based on a desert truffle tyrosinase extract immobilized into a sol-gel silica layered matrix. Journal of Sol-Gel Science and Technology, 2018, 86 (3), pp.675-681. 10.1007/s10971-018-4696-9 . hal-01826251

\section{HAL Id: hal-01826251 \\ https: / hal.sorbonne-universite.fr/hal-01826251}

Submitted on 29 Jun 2018

HAL is a multi-disciplinary open access archive for the deposit and dissemination of scientific research documents, whether they are published or not. The documents may come from teaching and research institutions in France or abroad, or from public or private research centers.
L'archive ouverte pluridisciplinaire HAL, est destinée au dépôt et à la diffusion de documents scientifiques de niveau recherche, publiés ou non, émanant des établissements d'enseignement et de recherche français ou étrangers, des laboratoires publics ou privés. 


\section{An optical catechol biosensor based on a desert truffle tyrosinase extract immobilized into a sol-gel silica layered matrix}

Saida Leboukh ${ }^{1,4}$, Hicham Gouzi ${ }^{2, *}$, Thibaud Coradin ${ }^{3, *}$, Harek Yahia ${ }^{4}$

${ }^{1}$ Centre Nationale de Recherche en Technologie Industrielle C.R.T.I Route de Dély-Ibrahim, B.P 64, Chéraga 16014 Alger, Algérie.

${ }^{2}$ Laboratoire de Chimie Organique, Substances Naturelles et Analyse (COSNA), Département de Chimie, Faculté des Sciences, Université Abou Bekr Belkaid, Tlemcen 13000, Algérie.

${ }^{3}$ Sorbonne Universités, UPMC Univ Paris 06, CNRS, UMR 7574, Laboratoire de Chimie de la Matière Condensée de Paris, 4 place Jussieu, 75005 Paris, France.

${ }^{4}$ Laboratoire d'Electrochimie et Chimie Analytique, Département de Chimie, Faculté des Sciences, Université Abou Bekr Belkaid, Tlemcen 13000, Algérie.

* corresponding authors:

Thibaud Coradin; e-mail: thibaud.coradin@upmc.fr; +33-1-44274018

Hicham Gouzi; e-mail: gouzi_h@yahoo.fr

ORCID ID: Thibaud Coradin - http://orcid.org/0000-0003-3374-5722 


\begin{abstract}
An optical biosensor for the determination of catechol, a widely used yet toxic and carcinogenic molecule, is proposed using a crude extract of desert truffle (Terfezia leonis Tul.) as an enzymatic source of tyrosinase. The biosensor is constructed by the immobilization of tyrosinase crude extract in a bi-layered silica gel film prepared by dip-coating of an alkoxide/colloidal silica solution containing the enzyme on glass slide. Encapsulation has a moderate effect of the enzyme optimal $\mathrm{pH}$ stability but largely increases its thermal stability. Immobilized enzymes have a higher substrate affinity towards catechol but smaller maximum conversion velocity. The optical biosensor provides a linear response for catechol in the concentration range of $50-400 \mu \mathrm{M}$ and a limit of detection was $52 \mu \mathrm{M}$. AFM studies show that the enzymes impact on the silica gel structure, preventing further deposition of additional layers. Comparison with similar dopamine biosensors points out that the impact of encapsulation on enzymatic activity may depend on the considered substrate.
\end{abstract}

Keywords: Optical Biosensor; Tyrosinase; Bioencapsulation; Silica; Catechol 


\section{Introduction}

Catechol is an important phenolic compound which is widely used in tanning, plastics, pesticides, dyes, cosmetics, and pharmaceutical industry, and is released into the environment as an industrial waste and a source of environmental pollution [1]. Moreover, it is toxic to humans and animals even at very low concentrations [2]. In consequence, it is crucial to establish a rapid and effective method to titrate catechol in contaminated waters.

Current methods for catechol detection include spectrophotometry, capillary electrophoresis, voltammetry and chromatography [3-6]. Catechol biosensors have also received considerable attention in recent years, using laccase and/or tyrosinase enzymes [7-11]. Tyrosinase is a copper-containing monooxygenase enzyme responsible for the first step of melanin pathway, starting from catechol as substrate leading to the formation of obenzoquinone, a strongly yellow colored product that can be used in simple optical bioassays $[12,13]$.

For the fabrication of enzymes biosensors, it is very important to choose the appropriate preparation method and film matrix for immobilizing enzymes; these factors can directly affect the activity, stability as well as other performances of the biosensor [14-17]. Among available technologies, the sol-gel bioencapsulation process, mainly involving silica-based materials, appears as a suitable approach to obtain chemically and physically-stable immobilization hosts, with tailorable porosity and good optical transparency [18-22]. In this context, the encapsulation of tyrosinase in silica-based materials for sensing or degradation purposes has already been reported [23-26].

In particular we have previously shown that a crude enzymatic extract of a desert truffle exhibiting polyphenol oxidase activity could be immobilized in a bilayered silica film and used for the detection of dopamine [27]. The advantage of this strategy is that it avoids the need for enzyme purification that is both time- and cost-consuming. 
In this work, we demonstrate that this approach can be extended to the design of a catechol biosensor but also show that the impact of encapsulation on the enzymatic activity depends on the considered substrate.

\section{Experimental}

\subsection{Extraction of tyrosinase}

The fresh black wild truffles (Terfezia leonis Tul.) for tyrosinase extraction were obtained from Algerian Southern. The protocol for extraction was described by Gouzi et al. [28]. First, $50 \mathrm{~g}$ of peridium from truffles were homogenized in $100 \mathrm{~mL}$ of $0.05 \mathrm{M}$ phosphate buffer $(\mathrm{pH} 7.0)$, using a Waring blender for $2 \mathrm{~min}$. The resulting homogenate was filtered through four layers of cheesecloth, and the filtrate was centrifuged for $10 \mathrm{~min}$ at 4,500 rpm. The supernatant (40 $\mathrm{mL})$ constituted the tyrosinase crude extract and was kept frozen at $-10^{\circ} \mathrm{C}$ until use.

\subsection{Preparation of tyrosinase-based biosensor}

The immobilization of the tyrosinase within silica layers was performed using a previously described method [27]. Briefly, $1.5 \mathrm{~mL}$ of a pre-hydrolyzed solution of tetraethoxysilane (TEOS) was mixed with $1.5 \mathrm{~mL}$ of colloidal silica LUDOX-HS 40 in acidic conditions $(\mathrm{pH}$ 2.0). The mixture was neutralized by addition of $1 \mathrm{~mL}$ of Tris- $\mathrm{HCl}(0.05 \mathrm{M}-\mathrm{pH} 8.6)$ containing $2 \%$ glycerol. Finally, $1 \mathrm{~mL}$ of the desert truffle tyrosinase crude extract was added. The resulting solution was placed in transparent cuvettes (1-cm width). After $30 \mathrm{~min}$ of ageing at room temperature, glass slides $(5 \mathrm{~mm} \times 45 \mathrm{~mm})$, which had been soaked in concentrated nitric acid for $24 \mathrm{~h}$ and washed with acetone, ethanol and distilled water, were immersed in this solution for $10 \mathrm{~s}$ and then slowly withdrawn $(\mathrm{rate}=0.25 \mathrm{~cm} / \mathrm{s})$. The films were dried for $30 \mathrm{~min}$ under ambient conditions and another dip-coating step was performed. The resulting two-layer films were place in an eppendorf tube containing sodium phosphate buffer (0.05 M-pH 7.0) and stored in the fridge $\left(4^{\circ} \mathrm{C}\right)$. 


\subsection{Free and immobilized tyrosinase activity assays}

The activity of free and immobilized tyrosinase was determined by using UV-vis Spectrophotometer (Amersham Biosciences UV/visible spectrophotometer Ultrospec ${ }^{\mathrm{TM}} 1100$ pro), by measuring of the initial rate of o-benzoquinone formation at $410 \mathrm{~nm}$. The reaction was initiated by adding appropriate enzyme amount or two layers of silica containing enzyme to catechol solution prepared in sodium phosphate buffer (0.05 M-pH 7.0).

\subsection{Optimum pH and thermal stability}

Thermal stability experiments were carried out with free and immobilized tyrosinase which were incubated in the absence of substrate at various temperatures $\left(30-60^{\circ} \mathrm{C}\right)$. The temperature stability was determined by assaying the residual activity after incubating enzymes at a given temperature for $10 \mathrm{~min}$. The heat-treated enzymes were rapidly cooled in an ice bath prior to assay for residual activity with catechol as substrate.

The optimum $\mathrm{pH}$ of free and immobilized enzyme was determined by carrying out the enzyme assay at different $\mathrm{pH}$ values using the following buffers: $0.05 \mathrm{M}$ sodium acetate/acetic acid ( $\mathrm{pH}$ 4.0-5.6); $0.05 \mathrm{M}$ monosodium dihydrogen phosphate-disodium hydrogen phosphate (pH 6.0-8.0). All measurements and pre-equilibration were carried out at $30^{\circ} \mathrm{C}$. The results for both $\mathrm{pH}$ and temperature were normalized, considering as $100 \%$ enzymatic activity the highest value obtained in each of the series of measurements made. All activity tests were conducted in triplicate.

\subsection{Determination of kinetic constants}

The kinetic constants, $\mathrm{K}_{\mathrm{m}}$ and $\mathrm{V}_{\max }$ values of the free and the immobilized tyrosinase were determined by measuring initial rates of the reaction with catechol at different concentrations $(0.5-20 \mathrm{mM})$ in phosphate buffer $(0.05 \mathrm{M}, \mathrm{pH} 7.0)$ at $30^{\circ} \mathrm{C}$. 
$\mathrm{K}_{\mathrm{m}}$ and $\mathrm{V}_{\max }$ values of the free and immobilized enzyme were calculated from LineweaverBurk plot from the initial rate of the reaction data obtained during enzymatic oxidation of catechol by using the Kaleidagraph software.

\subsection{Calibration curve of the tyrosinase-based optical biosensor}

To assess the biosensor performance, the optical density versus catechol concentration was plotted and the linearity domain determined via a linear regression model using the Kaleidagraph software.

\subsection{Characterization of surface morphology}

The surface morphology of silica sol-gel tyrosinase-based biosensor was investigated by atomic force microscopy, AFM (DI CPII, Veeco) using tapping mode, with commercially ultrasharpened $\mathrm{Si}_{3} \mathrm{~N}_{4}$ tips in a $3 \mu \mathrm{M} \times 3 \mu \mathrm{M}$ scanning area. The measurements were performed at air-ambient $\left(25^{\circ} \mathrm{C}\right.$ and $35 \%$ relative humidity). A tyrosinase-free film was also imaged for comparison. Sol-gel thin films were also characterized for refractive index and thickness using a Woollam M200-U variable-angle spectroscopic ellipsometer. The ellipsometric spectra recorded ranged from $250 \mathrm{~nm}$ to $900 \mathrm{~nm}$ with incident angle of $45^{\circ}$. Reflectance spectrum at an incident angle of $75^{\circ}$ was collected. A simple Cauchy's equation was used for modeling the optical properties of the porous silica films.

\section{Results and discussion}

\subsection{Optimal pH and thermal stability of free and immobilized tyrosinase}

$\mathrm{pH}$ is one of the most important factors influencing not only the side groups of the amino acid dissociations in the protein structure but also the solution chemistry of the insoluble support. $\mathrm{pH}$ therefore plays an important role in the sensing efficiency of the biosensor. The effect of $\mathrm{pH}$ on the activity of free and immobilized desert truffle tyrosinase towards was studied in the $\mathrm{pH}$ range 3.5-8.0 (Figure 1). The optimum $\mathrm{pH}$ for both the free and immobilized enzymes was observed at $\mathrm{pH}$ 7.0, in agreement with previous studies [23]. 
The immobilized tyrosinase also displayed significantly improved stability at lower and higher pHs compared to that of the free enzyme, as already widely reported for sol-gel encapsulated enzymes [29].

The thermal stability of an immobilized enzyme is one of the most important criteria of their application. In general, the activity of the immobilized enzyme is more resistant than that of the soluble form against heat and denaturing agents [30]. Below $30^{\circ} \mathrm{C}$, free and immobilized tyrosinase maintained their activity. After 10 min incubation at $50^{\circ} \mathrm{C}, 53 \%$ and $30 \%$ activity losses occurred for free and immobilized enzyme respectively (Figure 2). At $60{ }^{\circ} \mathrm{C}$, free enzyme was completely inactivated while immobilized enzyme maintained $40 \%$ of its initial activity. Therefore, immobilized tyrosinase showed better thermal stability than free enzyme at high temperatures. This may be attributed to the fact that the confinement of the enzyme within the silica matrix can prevent its unfolding [31].

\subsection{Kinetics parameters}

Maximum reaction rates, $\mathrm{V}_{\max }$, and Michaelis-Menten constants, $\mathrm{K}_{\mathrm{m}}$, were calculated using Lineweaver-Burk plot. $\mathrm{V}_{\max }$ and $\mathrm{K}_{\mathrm{m}}$ values for free and immobilized tyrosinase were determined at constant $\mathrm{pH}(\mathrm{pH}=7.0)$ and temperature $\left(\mathrm{T}=30^{\circ} \mathrm{C}\right)$ while varying catechol concentrations. The typical hyperbolic growth and saturation upon increasing the catechol concentration is evident in the Figure 3a. The kinetic parameters for encapsulated tyrosinase in silica matrix were obtained from a Lineweaver-Burk double reciprocal plot (Figure 3b), where the apparent Michaelis-Menten constant $\left(\mathrm{K}_{\text {mapp }}\right)$ and maximum velocity $\left(\mathrm{V}_{\text {maxapp }}\right)$ were 0.35 $\mathrm{mM}$ and $6 \mu \mathrm{M} \cdot \mathrm{min}^{-1}$, respectively. These values are significantly lower than those obtained for free tyrosinase $\left(\mathrm{K}_{\mathrm{m}}=2.5 \mathrm{mM} ; \mathrm{V}_{\max }=102 \mu \mathrm{M} \cdot \mathrm{min}^{-1}\right)$ using the same substrate.

The $K_{\text {mapp }}$ value reflects the affinity of the enzyme for the substrate; the smaller the $K_{\text {mapp }}$ value, the greater the affinity. Therefore, the affinity of immobilized tyrosinase for catechol is stronger than that of the free tyrosinase, in agreement with the literature [32]. In general, the 
$\mathrm{K}_{\mathrm{M}}$ of an immobilized enzyme is different from that of the free enzyme due to diffusional limitations, steric effects and ionic strength. The change in affinity of the enzyme to its substrate is probably caused by structural changes in the enzyme introduced by immobilization procedure. There is also partitioning of substrate between the solution and support so that the substrate concentration in the neighborhood of the enzyme may be significantly different from that in the bulk solution, leading to a decrease of the $\mathrm{V}_{\max }$ value upon immobilization.

\subsection{Biosensor performances}

Under the optimal conditions $\left(50 \mathrm{mM}\right.$ phosphate buffer solution $\left(\mathrm{pH} 7.0,30^{\circ} \mathrm{C}\right)$, we determined catechol concentration by spectrophotometry. The absorbance increased linearly and proportionally with the catechol concentration in the range $50-400 \mu \mathrm{M}$, following the equation $A b s_{410 \mathrm{~nm}}=2.6 \times 10^{-5}[\mathrm{Catechol}](\mu \mathrm{M})+3.6 \times 10^{-3}\left(\mathrm{r}^{2}=0.9924\right)($ Figure 4), indicating that the enzyme catalytic reaction of catechol is a first-order reaction. A deviation from a linear relationship between concentration catechol and absorbance was observed at high concentrations that can be explained by strong molecular interactions [33].

The data have been fitted to a straight line and the limit of detection (LOD) was calculated according to Miller and Miller [34]:

$L O D=\frac{\left(3 \times S_{y / x}\right)}{a}$

where a is the sensitivity of the method (the slope of the calibration curve) and $S_{\mathrm{y} / \mathrm{x}}$ is the standard deviation of the fit. The LOD was calculated to be $52 \mu \mathrm{M}$, in the upper limit of the acceptable concentration of phenolic compounds in treated wastewater [35].

Reproducibility and stability are important parameters to be considered for a biosensor. They were examined in the solution containing $2 \mathrm{mM}$ catechol. In terms of reproducibility, five different films were used and measurements were achieved with a variation coefficient of $4.7 \%$. In terms of operational stability, as seen in Figure 5, 30\% of initial tyrosinase activity was retained up to three cycles of reutilization. The decrease in the tyrosinase activity may be due 
to enzyme denaturation, leaching of enzyme from the carrier and due to inactivation of enzyme by catechol. In particular tyrosinases are prone to suicide inactivation resulting in the release of one of the two copper ions from the enzyme active site [36].

\subsection{Effect of the number of silica layers}

The optical response of tyrosinase biosensor depends on the amount of enzymes, which is a function of the number of assembled desert truffle tyrosinase silica layers. As seen on Figure 6 , the initial rate of catechol oxidation by the double-layer system studied above was twice as high as for a single silica-tyrosinase layer. However, when a third layer was deposited, this rate only increased moderately and in a less reproducible manner, suggesting that the coating process was only partially successful [37].

However, the possibility to obtain three successive silica layers following the same protocol, except for the absence of the tyrosinase, was previously reported [38]. We therefore hypothesized that the enzyme could impact on the structure of the deposited layers. AFM imaging of the surface of a two-layer silica-tyrosinase film showed a porous structure formed by the aggregation of well-defined nanoparticles $10-30 \mathrm{~nm}$ in diameter, with an average roughness $\mathrm{R}_{\mathrm{a}}$ of $17 \mathrm{~nm}$ (Figure 7a). The thickness and refractive index of one and two layers of silica films have been calculated from the ellipsometry data. A single layer had a thickness of $222 \pm 4 \mathrm{~nm}$ while the two layers were $362 \pm 5 \mathrm{~nm}$ thick. Refractive index under ambient conditions was $1.505 \pm 0.005$ for both conditions, confirming that the layers were porous.

As a comparison, the surface of an enzyme-free film showed a much denser network of aggregated nanoparticles with $\mathrm{R}_{\mathrm{a}}$ of $12 \mathrm{~nm}$ (Figure $7 \mathrm{~b}$ ). It indicates that the presence of the enzyme extract interferes with the process of gel formation. The resulting porosity may lead to the non homogenous deposition of the silica sol during the third coating step and therefore contribute to its poor reproducibility" 


\subsection{Comparison with related dopamine biosensors}

It is interesting to compare these results with a previous study describing dopamine biosensors prepared using the same enzymatic catalysts and the same sol-gel process [27]. In this previous work, the $\mathrm{pH}$ domain of maximum activity was extended over $2 \mathrm{pH}$ units compared to the enzyme alone and the optimal temperature was shifted by $c a .10^{\circ} \mathrm{C}$ after encapsulation. Since the enzyme and the matrices are the same, such a difference should mainly reflect modification of the substrate reactivity. It is possible to suggest that this is related to the presence of an additional alkylamine chain on the aromatic ring of dopamine compared to catechol, making the former more sensitive to the $\mathrm{pH}$ and the silica surface compared to the later. Noticeably, $\mathrm{K}_{\text {mapp }}$ and $\mathrm{V}_{\text {mapp }}$ variations resulting from encapsulation were of the same order of magnitude for both substrates. However they were determined in different optimal conditions for dopamine $\left(\mathrm{pH} 5.6, \mathrm{~T}=20^{\circ} \mathrm{C}\right)$ and catechol $\left(\mathrm{pH} 7.0, \mathrm{~T}=30^{\circ} \mathrm{C}\right)$, making a strict comparison difficult.

\section{Conclusions}

An optical biosensor allowing for catechol detection was obtained by encapsulation of a tyrosinase extract within a bi-layered silica film. It exhibits a linear response range over one concentration decade. However its limit of detection was in the upper range of recommended value for phenolic molecules content in treated wastewaters indicating that further efforts must be made, especially to increase the enzyme content of the device.

Considering the diversity of catalytic reactions that can be performed by tyrosinases, the hereproposed strategy may be extended to the detection of a wide range of other analytes, although our data suggest that the biosensor performance may significantly depend on the nature of the substrate. 


\section{Acknowledgments}

The authors thank Dr Marco Faustini and Dr Christophe Depagne (LCMCP) for AFM experiments and Dr. Cédric Boissière (LCMCP) for ellipsometry analysis. We would also like to thank Pr. Aziz Amine for her careful proofreading and copy-editing for grammar.

\section{Conflict of interest}

The authors report no conflicts of interest. The authors alone are responsible for the content and writing of the paper.

\section{References}

[1] Subramanyan R, Mishra IM (2007) Chemosphere 69:816-824

[2] Toxics Release Inventory Basis of OSHA Carcinogens, United States Environmental Protection Agency, Technical Update (March 2015)

[3] Tsai HC, Whang CW (1999) Electrophoresis 20:2533-2538.

[4] Xie T, Liu Q, Shi Y, Liu Q (2006) J Chromatogr A 1109:317-321.

[5] Lakshmi D, Bossi A, Whitcombe MJ, Cianella I, Fowler SA, Subrahmanyam S, Piletska EV, Piletsky SA (2009) Anal Chem 81:3576-3584.

[6] Wang Y, Li Y, Bao X, Han J, Xia J, Tian X, Ni L (2016) Talanta 160:195-204

[7] Rodriguez-Delgado MM, Aleman-Nava S, Rodriguez-Delgado JM, Dieck-Assad G, Martinez-Chapa SO, Barcelo D, Parra R (2015) TrAC 74:21-45.

[8] Uchiyama S, Hasebe Y, Shimizu H, Ishihara S (1993) Anal Chim Acta 276:341-345.

[9] Sapelnikova s, Dock E, Ruzgas T, Emneus J (2003) Talanta 61: 473-483

[10] Karim MN, Lee JE, Lee HJ (2014) Biosen Biolectron 61:147-151.

[11] Vicentini FC, Garcia LLC, Figueiredo-Filho LCS, Janegitz BC, Fatibello-Filho O (2016) Enzyme Microb Technol 84:17-23. 
[12] Zaidi KU, Ali AS, Naaz I (2014) Biochem Res Int 2014:ID 854687

[13] Fiorentino D, Gallone A, Fiocco D, Palazzo G, Mallardi A (2010) Biosens Bioelectron 25: $2033-2037$.

[14] Hernandez K, Fernandez-Lafuente R (2011) Enzyme Microb Technol 48:107-122.

[15] Sassolas A, Blum LJ, Leca-Bouvier BD (2012) Biotechnol Adv 30:489-511.

[16] Homaei AA, Sariri R, Vianello F, Stevanato R (2013) J Chem Biol 6: 185-205.

[17] Pospisilova M, Kuncova G, Trögl J (2015) Sensors 15:25208-25259.

[18] Livage J, Coradin T, Roux C (2001) J Phys Condens Matter 13:R673-691

[19] Pierre AC (2004) Biocatal Biotransformation 22:145-170.

[20] Avnir D, Coradin T, Lev O, Livage J (2006) J Mater Chem 16:1013-1030.

[21] Kandimalla VB, Trpathi VS, Ju H (2006) Crit Rev Anal Chem 36:73-106.

[22] David AE, Yang AJ, Wang NS (2011) Methods Mol Biol 679:49-66.

[23] Wang B, Zhang J, Dong S (2000) Biosens Bioelectron 15:397-402.

[24] Sani S, Muhid MNM, Hamdan H (2011) J Sol-Gel Sci Technol 59:7-18

[25] Wu S, Wang H, Tao S, Wang C, Zhang L, Liu Z, Meng C (2011) Anal Chim Acta 686:8186.

[26] Singh S, Jain DVS, Singla ML (2013) Sens Actuator B-Chem 182:161-169.

[27] Gouzi H, Moreau T, Depagne C, Coradin T (2013) Silicon 5:241-246.

[28] Gouzi H, Depagne C, Benmansour A, Coradin T (2013) Eur Food Res Technol 237:721729.

[29] Frenkel-Mullerad H, Avnir D (2005) J Am Chem Soc 127:8077-8081.

[30] Monsan P, Combes D (1988) Methods Enzymol 137:584-598.

[31] Chen YC, Smith T, Hicks RH, Doekhie A, Koumanov F, Wells SA, Edler KJ, van den Elsen J, Holman GD, Marchbank KJ, Sartbaeva A (2017) Sci Rep 7:46568.

[32] Donato L, Algieri C, Rizzi A, Giorno L (2014) J Memb Sci 454:346-350. 
[33] Dykstra P, Hao J, Koev ST, Payne GF, Yu L, Ghodssi R (2009) Sens Actuators B-Chem 138:64-70.

[34] Miller JN, Miller JC (2000) Statistics and Chemometrics for Analytical Chemistry, 4th ed. Prentice Hall, Harlow, England, New York

[35] Mandal A, Ojha K, De AK, Bhattacharjee S (2004) Chem Eng J 102:203-208.

[36] Land EJ, Ramsden CA, Riely PA (2007) Tohoku J Exp Med 212 :341-348

[37] Moreau T, Depagne C, Suissa G, Gouzi H, Coradin T (2013) J Mater Chem B 1:12351240.

[38] Depagne C, Masse S, Link T, Coradin T (2012) J Mater Chem 22:12457-12460. 


\section{Figure captions}

Figure 1. Optimum $\mathrm{pH}$ of free $(\bullet)$ and immobilized tyrosinase $(\circ)$.

Figure 2. Temperature stability of free $(\bullet)$ and immobilized tyrosinase $(\circ)$. The samples were incubated at different temperatures for $10 \mathrm{~min}$.

Figure 3. Michaelis-Menten (a) and Lineweaver-Burk (b) graphics of free $(\bullet)$ and immobilized tyrosinase (०).

Figure 4. Biosensor response as optical density at $410 \mathrm{~nm}$ after 3 min of contact with tyrosinase extract immobilized in two layers of silica. Measurements were performed in triplicates at $\mathrm{pH}$ 7.0- $30^{\circ} \mathrm{C}$.

Figure 5. Repeated uses of immobilized tyrosinase.

Figure 6. Increase of the rate of benzoquinone formation as a function of the number of silica layers. Catechol concentration was $2 \mathrm{mM}$.

Figure 7. AFM images of bilayered silica films (a) with and (b) without tyrosinase 
Figure 1

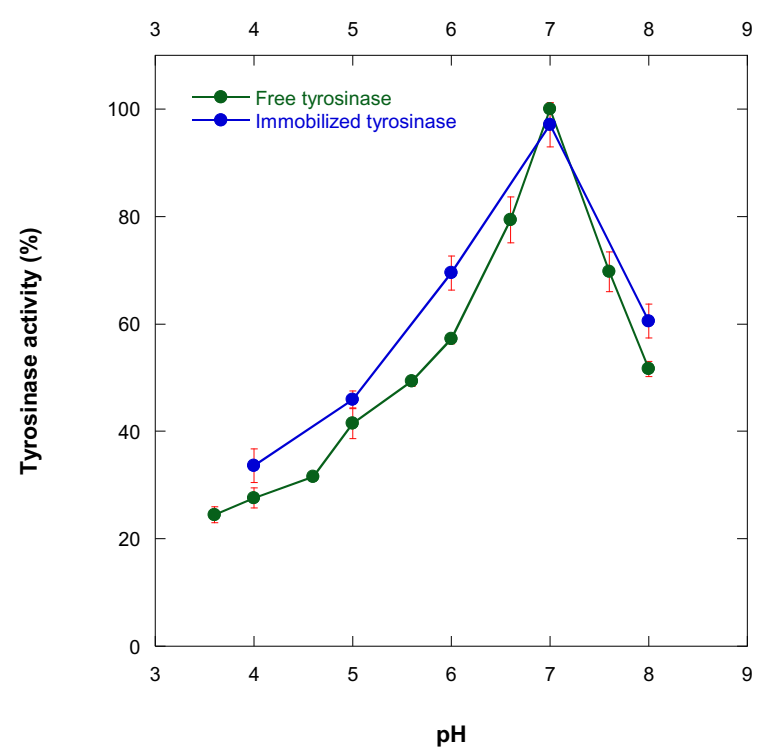


Figure 2

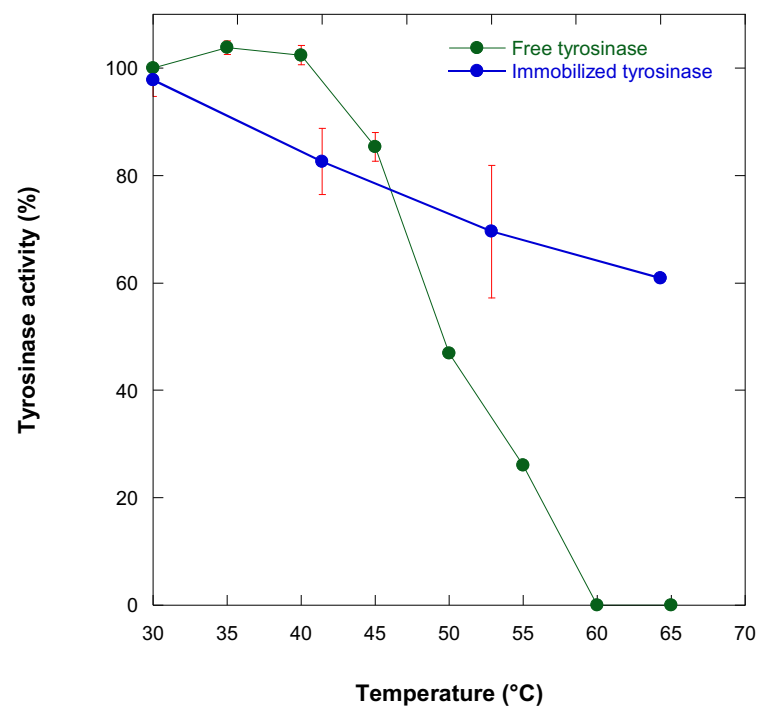


Figure 3
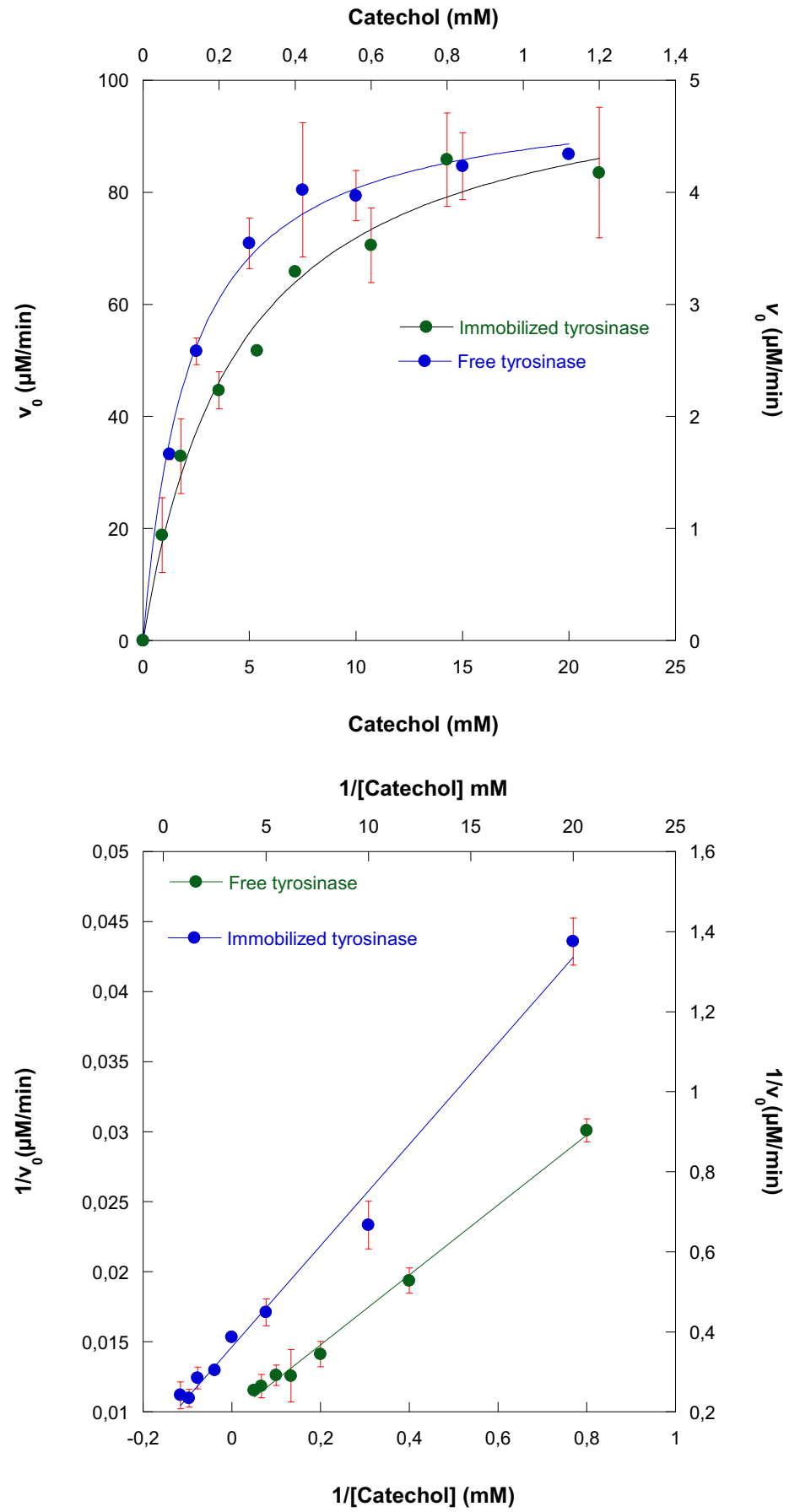
Figure 4

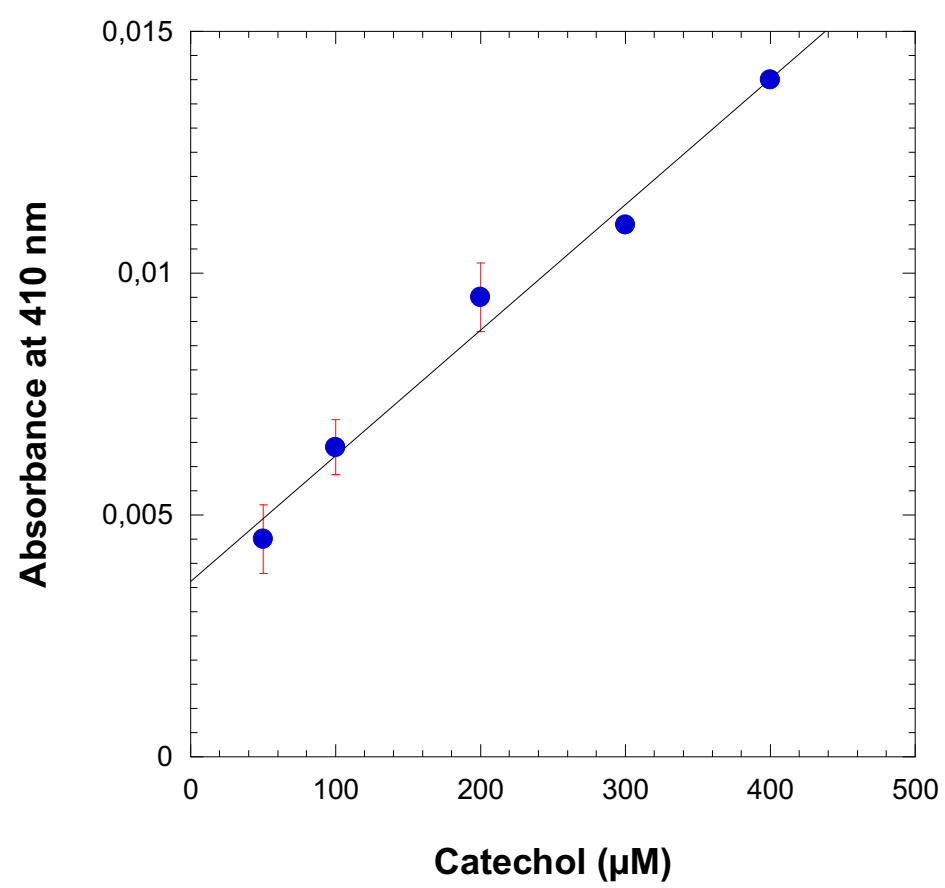


Figure 5

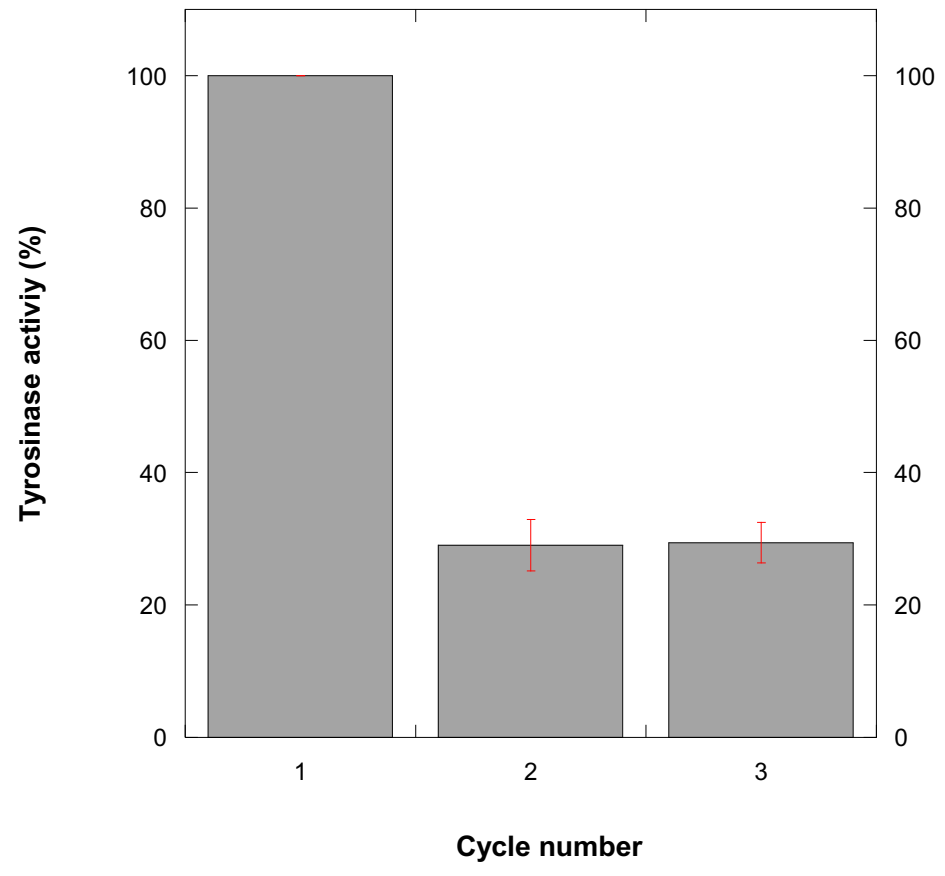


Figure 6

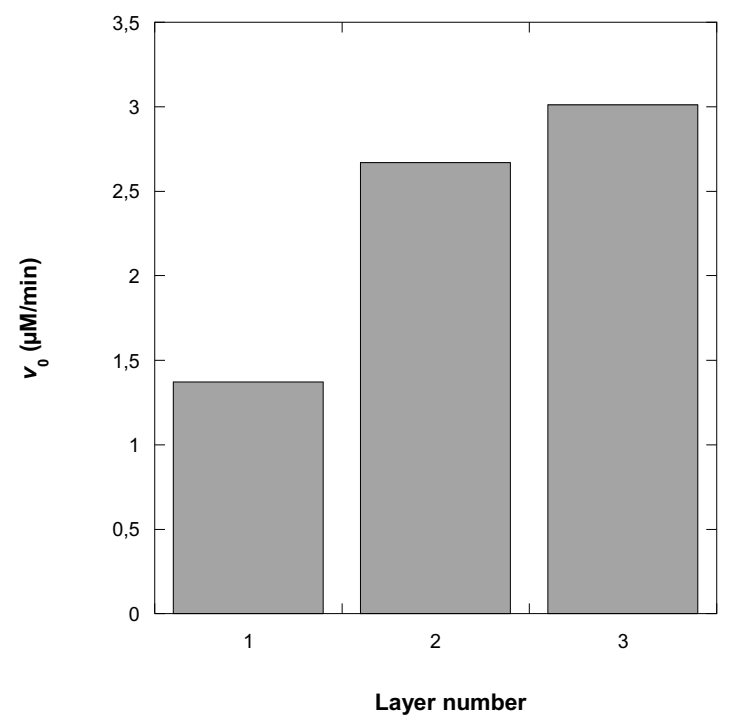




\section{Figure 7}
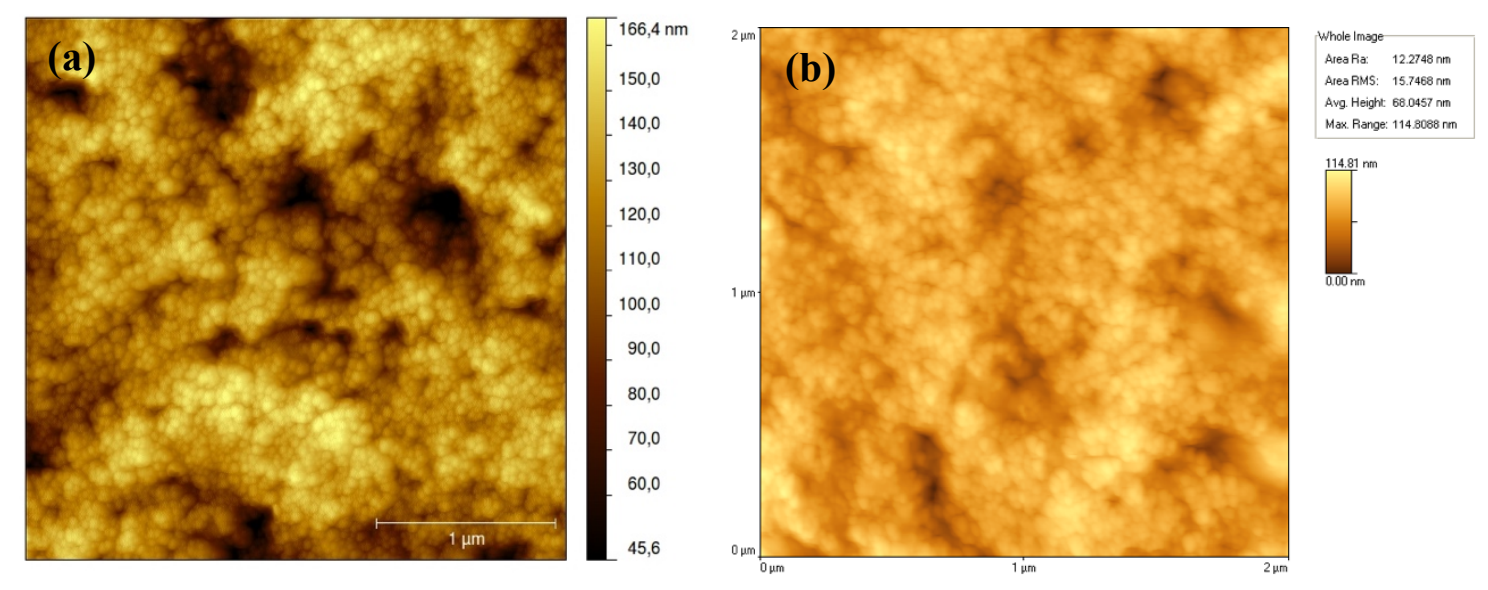